\begin{tabular}{|c|c|c|}
\hline \multirow[b]{2}{*}{ SFI I ENT } & Int.J.Curr.Microbiol.App.Sci (2021) 10(09): 54-58 & \\
\hline & $\begin{array}{l}\text { International Journal of Current Microbiology and Applied Sciences } \\
\text { ISSN: 2319-7706 Volume } 10 \text { Number } 09 \text { (2021) } \\
\text { Journal homepage: http://www.ijcmas.com }\end{array}$ & $\$ 9$ \\
\hline PUBLISHERS & & www.ijemas.com \\
\hline
\end{tabular}

\title{
Factors Influencing on Entrepreneurial Behavior of Turmeric Growers
}

\author{
V. G. Khawale*, U. R. Chinchmalatpure, V. B. Sonawane and S. V. Shelke \\ Department of Extension Education, Post Graduate Institute, \\ Dr. PDKV, Akola, Maharashtra, India \\ *Corresponding author
}

\section{A B S T R A C T}

Keywords

Entrepreneur,

Behaviour,

Turmeric,

Entrepreneurship

Article Info

Accepted:

10 August 2021

Available Online:

10 September 2021
The present study on "Entrepreneurial behaviour of turmeric growers" was conducted in Washim district of Maharashtra state with the objective to study the entrepreneurial behaviour of the turmeric growers. The exploratory research design of social research was used. In all, 120 respondents were selected by random sampling method. The data were collected by personally interviewing the respondents with the help of structured interview schedule. After analysis it was observed that majority of respondents $(40.00 \%)$ possess medium entrepreneurial behaviour. The results of the co-relation co-efficient between entrepreneurial behaviour of respondents and their profile results which clearly indicates that selected characteristics of turmeric growers i.e. Land holding, annual income, and knowledge had positive and significant relationship at 0.01 level of probability with entrepreneurial behaviour whereas, area under turmeric crop, extension contact and scientific orientation had positive significant relationship at 0.05 , percent level of probability with entrepreneurial behaviour of turmeric growers. While age, farming experience, source of irrigation had negative and nonsignificant relationship with entrepreneurial behaviour.

\section{Introduction}

India is known as the home of spices and produces a wide variety of spices like black pepper, cardamom, garlic, turmeric, chilli and a large variety of tree and seed spices.

Turmeric (Curcuma longa) is an herbaceous perennial plant and belongs to family Zingiberaceae which grows up to the height of
60-110 cm. with short stem and native of south Asia particularly, India. The plant is propagated through rhizomes.

A few years ago, India got the patent of turmeric due to strong evidences, ancient literature and references available with our country about the turmeric. The present era of liberation and globalization farmers can benefit from it by growing high quality 
turmeric and exporting it to the foreign countries to earn foreign exchange. This export will help in raising the economy of the country and farmers as well.

This will help to increase the earnings. India is the largest producer, consumer and exporter of turmeric in the world. Other major turmeric producers are Thailand, other Southeast Asian countries, Central, Latin America, and Taiwan.

The global production of turmeric is around 11 lakh tones per annum. India dominates the world production scenario contributing 78 per cent followed by China (8\%), Myanmar (4\%) and Nigeria and Bangladesh together contributing to 6 per cent of the global production.

Maharashtra state in India ranks sixth in area under turmeric cultivation. The area under crop was 14050 hectare with a production of 281000 tones, during 2017-18. In Maharashtra Sangli, Hingoli, Nanded, Parbhani, Chandrapur are the major turmeric growing districts. (Horticultural statistics at a glance 2018).

Recently since last few years the area under turmeric crop of Washim district in Vidarbha region is increasing day by day.

In Washim district of Maharashtra state, the area and production of turmeric is 1150 ha. and 23000 tones, with productivity 20 tons per hectare. (2018-19). There is great potential to increase production of this crop in future, if growers are oriented towards entrepreneurship and adoption of modern technology. Entrepreneurship is the dynamic process of creating incremental wealth. The wealth is created by individuals who take the major risks in terms of equity, time and career commitment of providing value to some products or services.(Source: SAO Akola).

\section{Materials and Methods}

The study was conducted in Washim district of Vidarbha region in Maharashtra state during 2019-2020. For the study of Entrepreneurial behaviour of turmeric growers, exploratory research design was used. In Washim district there are six tehsil out of these, two tehsil namely; Malegaon and Risod tehsils were selected.

From each of the selected tehsil, six villages were selected on the basis of maximum area under turmeric cultivation, from each selected village ten farmers were selected randomly.

Thus, from two selected tehsil ten villages were selected and from these villages, total 120 turmeric growers were selected and considered as sample in present study.

The data pertaining to selected variables were collected through a specially designed interview schedule in an informal atmosphere.

Entrepreneurial behavior of turmeric grower is operationally defined as cumulative outcome of seven selected components of entrepreneurial behaviour viz., innovativeness, achievement motivation, economic motivation, decision making ability, risk preference, leadership ability and management orientation was measured.

Entrepreneurial behavior was measured with the help of entrepreneurial behavior index by addition of scores of seven attributes namely innovativeness, achievement motivation, economic motivation, decision making ability, risk preference, leadership ability and management orientation.

The total obtained score was converted into entrepreneurial behavior index. The entrepreneurial behavior index was calculated by the following formula. 
Entrepreneurial Behaviour Index $=$

$\frac{\begin{array}{c}\text { Sum of obtained score on seven } \\ \text { entrepreneurial components }\end{array}}{\text { Maximum obtainable score }}$ X100

\section{Results and Discussion}

\section{Components of entrepreneurial behaviour of turmeric growers}

It is revealed from Table 1 that, as regards innovativeness component of entrepreneurial behavior of turmeric growers, majority $(68.34 \%)$ of the respondents belonged to medium innovativeness category, whereas majority $(65.83 \%)$ of the respondents belonged to medium achievement motivation category. Whereas majority $(55.83 \%)$ of the respondents belonged to medium category of economic motivation.

Further, majority $(54.16 \%)$ of the respondents belonged to medium category of decisionmaking ability, Majority $(73.33 \%)$ of the respondents belonged to medium category of risk preference, while majority $(52.50 \%)$ of the respondents belonged to medium category of leadership ability. Majority (67.50\%) of the respondents belonged to medium category of management orientation.

Similar findings reported by Shende (2019) and Yewatkar (2018).

\section{Overall Entrepreneurial behaviour of turmeric growers}

Distribution of the respondents according to their overall entrepreneurial behaviour is presented in Table.2. It is observed from the Table 2 that, majority $(40.00 \%)$ of the respondents possess medium entrepreneurial behaviour, followed by 32.5 per cent of respondents had high entrepreneurial behavior, whereas 27.5 per cent of respondents possess low entrepreneurial behaviour.

The above results are similar with the findings reported by Komal Gaware (2019) and Tekale (2015).

The data in table 3 revealed that, entrepreneurial behaviour of respondents and their profile revealed the following results which clearly indicates that selected characteristics of turmeric growers i.e. Land holding, annual income, and knowledge had positive and significant relationship at 0.01 level of probability with entrepreneurial behaviour whereas, area under turmeric crop, extension contact and scientific orientation had positive significant relationship at 0.05 percent level of probability with entrepreneurial behaviour of turmeric growers. While age, farming experience, source of irrigation had negative and non-significant relationship with entrepreneurial behaviour.

The above findings are supported with the findings reported by Jadhav (2003), Komal Gaware (2019), Sharma (2006), Shende (2019), Tekale (2015) and Yewatkar (2018).

The findings of the research revealed that majority of the turmeric grower had medium entrepreneurial behaviour, which indicates that turmeric growers are moving towards progress and for transformation of them from medium to high entrepreneurial behavior. The fact that majority of the farmers had medium level of adoption of recommended package of practices of turmeric is a clear indication of the adoptiveness of the turmeric growers is moving forward. As majority of the turmeric growers were middle and young aged and having medium level of knowledge, this group should be imparted training, so that they can act as catalysts in motivating other farmers through communication networks. 
Table.1 The turmeric growers were component wise classified into three categories viz. low, medium, high, respectively on the basis of mean and standard deviation as given below

\begin{tabular}{|c|c|c|}
\hline Sr. No. & Category & Index Range \\
\hline 1. & Low & Up to 63 \\
\hline 2. & Medium & 64 to 80 \\
\hline 3. & High & Above 80 \\
\hline
\end{tabular}

Mean $=71.53 \mathrm{SD}=8.94$

Table.2 Distribution of turmeric growers based on components of entrepreneurial behavior of turmeric growers

\begin{tabular}{|c|c|c|c|c|}
\hline \multirow{2}{*}{$\begin{array}{l}\text { Sr. } \\
\text { No. }\end{array}$} & \multirow[t]{2}{*}{ Components } & \multirow[t]{2}{*}{ Categories } & \multicolumn{2}{|c|}{ Respondents $(\mathrm{n}=120)$} \\
\hline & & & Frequency & Per cent \\
\hline \multirow{3}{*}{1.} & \multirow[t]{3}{*}{ Innovativeness } & Low & 31 & 25.83 \\
\hline & & Medium & 82 & 68.34 \\
\hline & & High & 07 & 05.83 \\
\hline \multirow{3}{*}{2.} & \multirow[t]{3}{*}{ Achievement motivation } & Low & 24 & 20.00 \\
\hline & & Medium & 79 & 65.83 \\
\hline & & High & 17 & 14.17 \\
\hline \multirow{3}{*}{3.} & \multirow[t]{3}{*}{ Economic motivation } & Low & 28 & 23.34 \\
\hline & & Medium & 67 & 55.83 \\
\hline & & High & 25 & 20.83 \\
\hline \multirow{3}{*}{4.} & \multirow[t]{3}{*}{ Decision making ability } & Low & 28 & 23.33 \\
\hline & & Medium & 65 & 54.17 \\
\hline & & High & 27 & 22.50 \\
\hline \multirow{3}{*}{5.} & \multirow[t]{3}{*}{ Risk preference } & Low & 23 & 19.17 \\
\hline & & Medium & 88 & 73.33 \\
\hline & & High & 09 & $\mathbf{0 7 . 5 0}$ \\
\hline \multirow{3}{*}{6.} & \multirow[t]{3}{*}{ Leadership ability } & Low & 29 & 24.17 \\
\hline & & Medium & 63 & 52.50 \\
\hline & & High & 28 & 23.33 \\
\hline \multirow{3}{*}{7.} & \multirow[t]{3}{*}{ Management orientation } & Low & 22 & 18.33 \\
\hline & & Medium & 81 & 67.50 \\
\hline & & High & 17 & 14.17 \\
\hline
\end{tabular}

Table.3 Distribution of the respondents according to their overall entrepreneurial behavior

\begin{tabular}{|c|c|c|c|}
\hline Sr. No. & Category & \multicolumn{2}{|c|}{ Respondents $(\mathbf{n = 1 2 0})$} \\
\cline { 3 - 4 } & & Frequency & Percentage \\
\hline 1. & Low ( Up to 63) & 33 & $\mathbf{2 7 . 5 0}$ \\
\hline 2. & Medium ( 64 to 80) & 48 & $\mathbf{4 0 . 0 0}$ \\
\hline $\mathbf{3 .}$ & High ( Above 80 ) & 39 & $\mathbf{3 2 . 5 0}$ \\
\hline & Total & $\mathbf{1 2 0}$ & $\mathbf{1 0 0 . 0 0}$ \\
\hline
\end{tabular}


Table.4 Relationship between profile of respondents and entrepreneurial behavior

\begin{tabular}{|c|c|c|}
\hline Sr. No. & Independent variables & Calculated ' $\mathbf{r}$ ' value \\
\hline $\mathbf{1 .}$ & Age & $-0.1273^{\mathrm{NS}}$ \\
\hline $\mathbf{2 .}$ & Education & $0.1415^{\mathrm{NS}}$ \\
\hline $\mathbf{3 .}$ & Land holding & $0.3060^{* *}$ \\
\hline $\mathbf{4 .}$ & Area under turmeric crop & $0.1717^{*}$ \\
\hline $\mathbf{5 .}$ & Annual income & $0.3742^{* *}$ \\
\hline $\mathbf{6 .}$ & Farming experience & $-0.1018^{\mathrm{NS}}$ \\
\hline $\mathbf{7 .}$ & Source of irrigation & $-0.0338^{\mathrm{NS}}$ \\
\hline $\mathbf{8 .}$ & Extension contact & $0.1954^{*}$ \\
\hline $\mathbf{9 .}$ & Scientific orientation & $0.1954^{*}$ \\
\hline $\mathbf{1 0 .}$ & Knowledge & $0.3593^{* *}$ \\
\hline
\end{tabular}

** = Significant at 0.01 per cent level of probability

$*=$ Significant at 0.05 per cent level of probability

NS Non-Significant

\section{References}

Jadhav, D. B., 2003. A study on entrepreneurial behaviour of watermelon growers in Ratnagiri district. M.Sc. (Agri.) thesis (Unpub.), Dr. BSKKV, Dapoli.

Komal Gaware, 2019. Entrepreneurial behavior of onion seed producers. M.Sc. (Agri.) thesis (Unpub.), Dr.PDKV, Akola.

Sharma Pawan, 2006. A study on entrepreneurial behavior of garlic producers of Agri.-export Zone for garlic in Madhya Pradesh. M.Sc. (Agri.) thesis, JNKVV. College of Agriculture, Indore.

Shende, S. S., 2019. Entrepreneurial behaviour of turmeric growers in Hingoli district. M.Sc. (Agri.) thesis (Unpub.) VNMKV, Parbhani.

Tekale, V. S., 2015. Entrepreneurial behavior of vegetable growers. Research Review Committee Report, Dr. PDKV, Akola: 351-354.

Yewatkar, H. D., 2018, Entrepreneurial behaviour of garlic growers. M.Sc. (Agri.) Thesis, (Unpub.), Dr. PDKV, Akola.

\section{How to cite this article:}

Khawale, V. G., U. R. Chinchmalatpure, V. B. Sonawane and Shelke, S. V. 2021. Factors Influencing on Entrepreneurial Behavior of Turmeric Growers. Int.J.Curr.Microbiol.App.Sci. 10(09): 54-58. doi: https://doi.org/10.20546/ijcmas.2021.1009.006 